\title{
Environmental effects on performance of progeny from different Nellore sires in Brazilian semiarid region
}

\author{
Fatores ambientais sobre o desempenho de progêniesde diferentes touros da raça \\ Nelore no semiárido brasileiro
}

FERNANDES, Luis Miguel Gonçalves ${ }^{1 *}$; MOTA, Iara Souza ${ }^{1}$; PAULA, Brenda Marques de ${ }^{1}$; OLIVA, Raquel Gonçalves ${ }^{1}$; CUNHA, Gabriel Santos Persiquini ${ }^{1}$, CHAVES, Amália Saturnino ${ }^{1}$

${ }^{1}$ Federal University of Minas Gerais, Institute of Agricultural Sciences, Montes Claros, Minas Gerais, Brazil.

*Correspondingauthor: miguelgfff@hotmail.com

\section{SUMMARY}

The aim of this study was to evaluate the influence of environmental factors on the performance of progeny from different Nellore sires in Brazilian semiarid region. Data on live weight, average daily gain and scrotal circumference of 741 animals categorized as OR (open registry) or PB (purebred) and born from 27 sires were collected from a commercial farm located in Varzelândia-MG. Evaluations were taken at 12 (yearling) and 18months of age. Data were analyzed using the least-squares method, considering the effect of pedigree (OR or PB), sire, year of birth, month of birth and calf sex in the model. There was a significant influence of the pedigree, sex, month of birth and sire on animal's performance until yearling age, whereas the performance traits at 18 months were influenced only by the month of birth and sire $(\mathrm{P}<0.05)$. Therefore, environmental factors such as year, month of birth and calf sex are important sources of variation on calf performance from birth to18 months and it should be considered when comparing and selecting animals based on these traits.

Keywords: Average daily gain, month of birth, Bos indicus, genetic improvement, scrotal circumference

\section{RESUMO}

O objetivo deste trabalho foi avaliar a influência dos fatores ambientais sobre o desempenho das progênies de diferentes touros da raça Nelore no semiárido brasileiro. Informações de 741 animais foram coletadas de uma fazenda comercial localizada no munícipio de Varzelândia-MG. Os animais eram filhos de 27 touros da raça Nelore e eram categorizados como LA (livro aberto) ou PO (puros de origem). Foram avaliados os dados de peso, ganho de peso médio diário e perímetro escrotal. As avaliações foram realizadas aos 12 (ano) e 18 (sobreano) meses de idade. Os dados foram analisados pelo método dos quadrados mínimos, utilizando um modelo que considerou efeito de categoria (LA ou PO), touro, anos, mês de nascimento e sexo dos bezerros. Houve influência significativa da categoria, sexo, mês de nascimento e touro sobre o desempenho dos animais até o ano, enquanto as características de desempenho ao sobreano foram influenciadas somente pelo mês de nascimento e touro $(\mathrm{P}<0,05)$. Sendo assim, os fatores do meio como ano e mês de nascimento e sexo do bezerro são importantes fontes de variação sobre o desempenho dos bezerros do nascimento até o sobreano, devendo, portanto, ser 
consideradas na comparação e seleção de animais com base nestas características.

Palavras-chave: Bos indicus, ganho médio diario, melhoramento genético, mês de nascimento, perímetro escrotal. 


\section{INTRODUCTION}

Brazilian beef production is projected to increase strongly in coming decades, with an expectation to grow $2.1 \%$ a year from $2016 / 17$ to $2026 / 27$, while beef exports should increase by $3.0 \%$ annually (USDA, 2017).

It is estimated that $80 \%$ of ruminant animals destined for meat production in Brazil are Zebu and their crosses (ABCZ, 2016). Greatly important for the national livestock system, Nellore breed represents about $80 \%$ of these Zebu animals. Therefore, it is essential to maximize their performance because the productivity of the Brazilian herd is still considered low in relation to the other countries. In this sense, the use of genetically improved sires has been an alternative for the livestock sector, since the investment in high quality genetics has a potential return, thus increasing farm income.

Growth traits in the pre- and postweaning phases have genetic variability and it can be included in genetic improvement programs because they are responsive to individual selection (SOUZA et al., 2000). Therefore, the live weight becomes an essential tool in the selection process to evaluate the animal's potential to gain weight, helping to choose early maturing cattle.

However, animal-environment interaction is responsible for phenotypic differences and, consequently, animal performance may vary widely. This variation is associated with several factors such as genetic differences between sires and dam, sanitary,

reproductive and nutritional management aspects of each region, as well as the sex and the month of birth of the progeny (SOUZA et al., 2000).
To obtain satisfactory results in beef cattle production, it is important to observe that the environmental and management conditions can influence performance traits. Therefore, it is necessary to study offspring productivity considering the environmental conditions and production system adopted. The aim of this study was to evaluate the influence of environmental factors on performance of progeny from different Nellore sires in the Brazilian semiarid region.

\section{MATERIAL AND METHODS}

Data were collected in a commercial farm in Varzelândia, MG, located at latitude $15^{\circ} 42^{\prime} 05^{\prime \prime S}$ and longitude $44^{\circ} 01^{\prime} 39^{\prime \prime} \mathrm{W}$. Varzelandia has a

semiarid climate, with high temperatures and precipitation concentrated over a few months, resulting in prolonged drought periods of up to nine months.

Data from 741 Nellore animals were used, of which 388 were classified as OR (open registry) and $353 \mathrm{~PB}$

(purebred) animals, born from September 2013 to February 2014, progeny of 27 Nellore sires. Nellore herd book is open to animals (recorded as open registry) who conform to the breed standard by meeting a certain conformation according to the Brazilian Association of Zebu Cattle Breeders, but with no previously registry of their earlier ancestors.

Data on date of birth, pedigree, weaning weight (WW), yearling weight (YW), 18-month weight (18W), yearling scrotal circumference (YSC) and 18month scrotal circumference (18SC) of male progeny were collected. 
Evaluations were taken at 12 (yearling) and 18 months of age. From the total of 741 animals, 672 were evaluated at weaning and 651 were evaluated at 18 months, although not all the animals that were measured at the yearling age were assessed at weaning. Therefore, those animals were not considered in the analysis. In addition, 581 animals were evaluated at18months, but for 18 SC only 267 animals were assessed.

Taken this information above, the average daily gain from birth to weaning (ADGW), average daily gain from birth to yearling age (ADGY) and to 18-month (ADG18) were calculated.
Weaning weight was adjusted to 205 days of age, and ADGW, ADGY and ADG18were obtained by the ratio between the WW, YW and $18 \mathrm{~W}$ observed, and the estimated birth weight $(\mathrm{BW})$, by the number of days between two observations.

Data on each trait were analyzed using PROC GLM (SAS, 2004) to generate least-squares means, using a model that considers the effect of pedigree (OR or $\mathrm{PB})$, sire, year, month of birth and calf sex. For scrotal circumference traits, the effect of sex was not included in the statistical model.

In which:

$$
Y j k l m n=\mu+G j+S k+M l+A m+T n+\text { ejklmn }
$$

Yjklmn $=$ Represent the value observed for the trait Yof the n-th animal, of the $\mathrm{j}$-th pedigree; of the k-th sex; born in the $\mathrm{m}$-th year and 1-th month, progeny of the $n$-th sire; $\mu=$ overall mean of trait $Y ; G j=$ fixed effect of the $j$-th pedigree $(j=O R$ and $P B) ; S k=$ fixed effect of the k-th sex of the calf $(\mathrm{k}=1$, male and 2 , female); $\mathrm{Ml}=$ fixed effect of the 1-th month of birth $(1=9,10,11,12,01,02)$; $\mathrm{Am}=$ fixed effect of the m-th year of birth $(\mathrm{m}=2013$ and 2014); $\mathrm{Tn}=$ fixed effect of $n$-sire $(n=1,2,3 \ldots 27)$; ejklmn $=$ random error associated with each observation.

\section{RESULTS AND DISCUSSION}

The mean values observed for WW and ADGW were $208.53 \pm 40.17 \mathrm{~kg}$ and $0.871 \pm 0.196 \mathrm{~kg} / \mathrm{day}$, whereas for 18 month a decline in body growth velocity was observed, with the mean weight gain of $0.411 \pm 0.063 \mathrm{~kg} /$ day (Table 1). These values were similar to those found by other authors (LAUREANO et al., 2011; PANETO et al., 2002; SARMENTO et al., 2003).

Table 1. Number of observations (N), mean, minimum (Min), maximum (Max) and respective standard deviations (SD) for weaning weight ${ }^{1}$ (WW), average daily gain at weaning (ADGW), yearling weight ${ }^{2}(\mathrm{YW})$, average daily gain up to yearling age (ADGY), 18-month weight ${ }^{3}(18 \mathrm{~W})$, average daily gain up to 18-month (ADG18), yearling (YSC) and 18-month (18SC) scrotal circumference.

\begin{tabular}{llllll}
\hline Trait & $\mathrm{N}$ & Mean & Min & Max & SD \\
\hline WW, kg & 672 & 208.5 & 117.0 & 373.0 & 40.17 \\
ADGW, & 672 & 0.871 & 0.268 & 1.673 & 0.196 \\
kg/day & & & & & 42.31 \\
YW, kg & 651 & 223.3 & 107.0 & 392.0 & \\
\hline
\end{tabular}


http://dx.doi.org/10.1590/S1519-994020 0722019

\begin{tabular}{lccccc} 
ADGY, & 651 & 0.530 & 0.211 & 0.992 & 0.116 \\
kg/day & & & & & \\
$18 W, \mathrm{~kg}$ & 581 & 20.52 & 16.00 & 28.00 & 2.391 \\
$\begin{array}{l}\text { ADG18, } \\
\text { kg/day }\end{array}$ & 581 & 256.0 & 167.0 & 397.0 & 35.07 \\
YSC, cm & 581 & 0.411 & 0.249 & 0.667 & 0.063 \\
$18 S C$, cm & 267 & 21.82 & 16.00 & 30.00 & 2.550 \\
\hline${ }^{1}$ Weaning=205 days; & \\
\end{tabular}

When studying the growth traits of Nellore cattle, Laureano et al. (2011) observed mean values of $0.74 \mathrm{~kg} / \mathrm{day}$ and $0.31 \mathrm{~kg} /$ day forweight gain from birth to weaning and from weaning to 18 months, respectively. The weight gain at different stages of the animal's life can be used as selection criterion, since it is a trait of high heritability and a good indicator of the growth potential of an individual.
There was a significant influence of the pedigree, sex, month of birth and sire on animal's performance until yearling age, whereas the performance traits at 18 months were influenced only by the month of birth and sire $(\mathrm{P}<0.05$; Table2). Therefore, all sources of variation included in the model

influenced animal performance, evidencing the importance of each one of these factors when comparing and choosing sires.

Table 2. Summary of analysis of variance for weaning weight ${ }^{1}$ (WW), average daily gain at weaning (ADGW), yearling weight ${ }^{2}(\mathrm{YW})$, average daily gain up to yearling age (ADGY), 18-month weight ${ }^{3}(18 \mathrm{~W})$ and average daily gain up to 18-month (ADG18) of PB (purebred) and OR (open registry) Nellore cattle

\begin{tabular}{|c|c|c|c|c|c|c|c|}
\hline \multicolumn{8}{|c|}{ Mean Squares } \\
\hline SV & $\mathrm{DF}$ & $\mathrm{WW}(\mathrm{kg})$ & $\begin{array}{l}\text { ADGW } \\
\text { (kg/day) }\end{array}$ & YW(kg) & $\begin{array}{l}\text { ADGY } \\
\text { (kg/day) }\end{array}$ & $18 \mathrm{~W}(\mathrm{~kg})$ & $\begin{array}{l}\text { ADG18 } \\
\text { (kg/day) }\end{array}$ \\
\hline PB/OR & 1 & $58968 * * *$ & 1.403 & $83275 * * *$ & $0.625 * * *$ & 2199 & 0.007 \\
\hline Sex & 1 & $40470 * * *$ & $0.962^{*}$ & $251504 * * *$ & $1.887 * * *$ & 2228 & 0.007 \\
\hline MB & 5 & $29731 * * *$ & $0.707 * * *$ & $51444 * * *$ & $0.385^{* * *}$ & $51018 * * *$ & $0.168 * * *$ \\
\hline Sire & 19 & $3172 * *$ & $0.075^{* *}$ & $1641 *$ & $0.012 *$ & $1512 * *$ & $0.004 * *$ \\
\hline $\mathbf{R}^{2}(\%)$ & & 28.47 & 28.48 & 53.54 & 53.53 & 40.40 & 40.36 \\
\hline $\mathrm{CV}(\%)$ & & 16.61 & 19.40 & 13.17 & 15.22 & 10.82 & 12.25 \\
\hline
\end{tabular}

Regarding the pedigree, PB animals had higher performance up to the yearling age compared to OR offspring (Table 3). The WW of PB animals (223.7 \pm
$38.26 \mathrm{~kg}$ ) was $8.76 \%$ higher than that of OR progeny $(204.1 \pm 38.26 \mathrm{~kg})$, leading to a greater performance at the yearling age, with an YW10.55\% and ADGY 
$12.02 \%$ higher than those of OR pedigree, respectively. Ribeiro et al. (2012), when evaluating PB and OR Nellore cattle in feedlot, did not observe differences in weight gain and carcass traits, even though PB animals were considered more genetically selected within-breed. However, according to the same author, these results can be explained due to the similarity in the selection process between these animals. This fact is justified because the Brazilian Association of Zebu Cattle Breeders considers that third-generation crosses of ORxPB cattle are PB animals (RIBEIRO et al, 2012).

Table 3. Number of observations (N), and estimated means forweaning weight ${ }^{1}$ (WW), average daily gain at weaning (ADGW), yearling weight ${ }^{2}(\mathrm{YW})$, average daily gain up to yearling age (ADGY), 18-month weight ${ }^{3}(18 \mathrm{~W})$, average daily gain up to 18-month (ADG18), yearling (YSC) and 18-month (18SC) scrotal circumference of male (M) or female (F) Nellore PB (purebred) and OR (open registry) cattle

\begin{tabular}{llllllllll}
\hline Pedigree & $\mathrm{N}$ & $\begin{array}{l}\mathrm{WW} \\
(\mathrm{kg})\end{array}$ & $\begin{array}{l}\text { ADGW } \\
(\mathrm{kg} / \mathrm{day})\end{array}$ & $\begin{array}{l}\text { YW } \\
(\mathrm{kg})\end{array}$ & $\begin{array}{l}\text { ADGY } \\
(\mathrm{kg} / \mathrm{day})\end{array}$ & $\begin{array}{l}18 \mathrm{~W} \\
(\mathrm{~kg})\end{array}$ & $\begin{array}{l}\text { ADG18 } \\
(\mathrm{kg} / \text { day })\end{array}$ & $\begin{array}{l}\text { YSC } \\
(\mathrm{cm})\end{array}$ & $\begin{array}{l}18 \mathrm{SC} \\
(\mathrm{cm})\end{array}$ \\
\hline PB & 353 & 223.7 & 0.944 & 239.8 & 0.574 & 263.2 & 0.423 & 20.72 & 21.73 \\
OR & 388 & 204.1 & 0.849 & 214.5 & 0.505 & 253.3 & 0.405 & 20.19 & 21.17 \\
Sex & & & & & & & & \\
$\mathrm{F}$ & 358 & 206.3 & 0.860 & 207.8 & 0.487 & 257.7 & 0.414 & - & - \\
$\mathrm{M}$ & 383 & 221.4 & 0.933 & 246.5 & 0.593 & 258.7 & 0.415 & - & - \\
\multicolumn{1}{l}{${ }^{1}$ Weaning=205 days; ${ }^{2}$ Yearling=12 months; ${ }^{3} 18$ months. }
\end{tabular}

When the influence of sex was assessed, males $(221.4 \pm 38.26 \mathrm{~kg})$ were weaned $15.1 \mathrm{~kg}$ heavier than females $(206.3 \pm$ $38.26 \mathrm{~kg}$ ), showing a superiority of $6.77 \%$. Consequently, males had aADGY $17.87 \%$ higher $(0.593 \pm 0.11$ $\mathrm{kg} / \mathrm{day})$ than females $(0.487 \pm 0.11$ $\mathrm{kg} / \mathrm{day}$ ) (Table 3). However, animal performance did not have the same behavior for 18-monthtraits. Other studies also observed a superiority of the males' growth potential over females at weaning (SOUZA et al., 2000, 2004). The high rate of growth of males can be justified due to the increased conversion of androgens into estrogens, stimulating the growth (FERRAZ FILHO et al., 2001; MARTINS et al., 2000).

Regarding the month of birth, it was verified that animals born between the months of September and December had higher performance in relation to animals born in January and February (Table 4). 
Table4.Estimated means for weaning, weight ${ }^{1}$ (WW), average daily gain at weaning(ADGW), yearling weight $(\mathrm{YW})$, average daily gain up to yearling age (ADGY), 18-month weight ${ }^{3}(18 \mathrm{~W})$, average daily gain up to 18 -month (ADG18), yearling (YSC) and 18-month (18SC) scrotal circumference of PB (purebred) and OR (open registry) Nellore cattle born in different months

\begin{tabular}{lllllllll}
\hline $\begin{array}{l}\text { Month/Year of } \\
\text { Birth }\end{array}$ & WW(kg) & $\begin{array}{l}\text { ADGW } \\
(\mathrm{kg} / \text { day })\end{array}$ & $\begin{array}{l}\text { YW } \\
(\mathrm{kg})\end{array}$ & $\begin{array}{l}\text { ADGY } \\
(\mathrm{kg} / \mathrm{day})\end{array}$ & $\begin{array}{l}18 \mathrm{~kg} \\
(\mathrm{~kg})\end{array}$ & $\begin{array}{l}\text { ADG18 } \\
(\mathrm{kg} / \mathrm{day})\end{array}$ & $\begin{array}{l}\text { YSC } \\
(\mathrm{cm})\end{array}$ & $\begin{array}{l}18 \mathrm{SC} \\
(\mathrm{cm})\end{array}$ \\
\hline $\begin{array}{l}\text { September } \\
2013\end{array}$ & 288.6 & 1.261 & 294.6 & 0.725 & 328.9 & 0.543 & 23.67 & 25.00 \\
October 2013 & 222.6 & 0.939 & 243.5 & 0.585 & 276.2 & 0.447 & 21.56 & 22.94 \\
November 2013 & 205.6 & 0.856 & 230.0 & 0.548 & 264.4 & 0.426 & 20.84 & 21.96 \\
December 2013 & 205.3 & 0.855 & 215.4 & 0.508 & 245.6 & 0.392 & 19.33 & 20.77 \\
January 2014 & 193.2 & 0.796 & 197.2 & 0.458 & 228.6 & 0.361 & 18.75 & 19.58 \\
February 2014 & 167.9 & 0.672 & 182.1 & 0.416 & 205.5 & 0.319 & 18.58 & 18.42 \\
\hline 1 Weaning=205 days; ${ }^{2}$ Yearling=12 months; ${ }^{3}$ 18 months. & & & &
\end{tabular}

Progeny born between September and December had higher WW (230.52 \pm $38.26 \mathrm{~kg})$ and $\mathrm{ADGW}(0.977 \pm 0.18$ $\mathrm{kg} /$ day) in relation to calves born in January and February (WW=183.36 \pm $38,26 \mathrm{~kg}$ and $\mathrm{ADGW}=0.734 \mathrm{~kg} / \mathrm{day} \pm$ $0.18 \mathrm{~kg} /$ day), resulting in a noticeable difference in live weight of $119 \mathrm{~kg}$ between animals born in September and January. The lighter calves were weaned with $167.9 \pm 38.26 \mathrm{~kg}$, were born in February and had values $12.72 \%$ lower than those born in September. Alencar et al. (1997) analyzed the performance of calves born from Nellore and Canchim sires and crossbred (F1) Charolais X Nellore and Piedmont $\mathrm{x}$ Nellore sires, and they concluded that animals born between June and September were the lightest calves at weaning. Souza et al. (2000), evaluating weaning weights of calves, also concluded that animals born at the end of the dry season are those that perform better. This is justified because of the greater availability of feed to dams in the final third of gestation, favoring the weaning of heavier calves.
Regarding the sire effect, a significant influence was observed for all evaluated traits in the pre and post weaning phases, as previously mentioned ( $\mathrm{P}<0.05$; Table 2). Rosa (2015), evaluating the difference between progeny of commercial sires and genetically improved sires using genetic evaluation data from Embrapa Beef Cattle Breeding Program-Geneplus, found an increase in live weight of 3.9 $\mathrm{kg}$ in progeny born from improved sires compared to commercial bulls. Therefore, the use of genetically superior sires brings a great economic return and increases the productivity in beef cattle herds.

In relation to the $\mathrm{SC}$, the observed mean $(21.77 \pm 2.47 \mathrm{~cm})$ is below the values found for the Nellore breed, ranging from 26.0 to $28.3 \mathrm{~cm}$ in animals with the same mean age (BOLIGON et al., 2007; FORNI \& ALBUQUERQUE, 2005; LAUREANO et al., 2011). Silva et al. (2002), analyzing the relationship between SC and semen quality of 960 Nellore sires, found an average SC of $25.71 \mathrm{~cm}$ for males at 18 months. Lima et al. (2013), studying SC and seminal 
characteristics of 24 Nellore sires selected for sexual precocity, observed values of scrotal circumference of 22.37 $\mathrm{cm}$ at 12 months, $28.43 \mathrm{~cm}$ at 14 months, $29.45 \mathrm{~cm}$ at 16 months and $30.77 \mathrm{~cm}$ at 18 months. Such variation might be justified because the animals in the present study may have been

negatively influenced by low precipitation and low pasture quality in the semiarid region and they were not selected for sexual precocity as in most of the studies cited above, resulting in smaller scrotal circumferences in relation to the literature.

There was significant influence of the month of birth and sire on the YSC and $18 \mathrm{SC}$, but the scrotal circumference was influenced by the OR or PB pedigree only until 12 months of age $(\mathrm{P}<0.05$; Table 5). Animals born between September and November had higher
YSC $(22.2 \pm 2.37 \mathrm{~cm})$ and 18SC (23.3 $\mathrm{cm} \pm 2.54)$ than animals born between December and February (YSC $=19.0 \pm$ $2.37 \mathrm{~cm}$ and $18 \mathrm{SC}=19.6 \pm 2.54 \mathrm{~cm})$, a result similar to the performance of progeny evaluated within the same

growth phase. The scrotal circumference as well as the post-

weaning performance may be influenced by environmental factors. Progeny born in September, October and November had higher mean values for 18SC, which may be justified due to the greater performance of animals born at the end of the dry period and beginning of the wet season, as a result of the higher precipitate on levels and feed availability at that time. These results suggest that phenotypic variability in SC expression can also be influenced by environmental conditions.

Table 5. Summary of analysis of variance for yearling scrotal circumference ${ }^{1}$ (YSC) and 18-month scrotal circumference ${ }^{2}$ (18SC) of PB (purebred) and OR (open registry) Nellore cattle

\begin{tabular}{|c|c|c|c|}
\hline \multicolumn{4}{|c|}{ Mean Squares } \\
\hline SV & DF & YSC $(\mathrm{cm})$ & $18 \mathrm{SC}(\mathrm{cm})$ \\
\hline $\mathrm{PB} / \mathrm{OR}$ & 1 & $30.38 * *$ & 12.38 \\
\hline MB & 5 & $110.6 * * *$ & $105.5 * * *$ \\
\hline Sire & 19 & $7.072 *$ & $7.935^{*}$ \\
\hline $\mathrm{R}^{2}(\%)$ & & 38.73 & 39.98 \\
\hline CV (\%) & & 9.49 & 9.50 \\
\hline
\end{tabular}

It is observed an influence of SC on both weight traits such as WW and $18 \mathrm{~W}$, and on reproductive traits such as seminal characteristics. It is known that there is a high correlation between scrotal circumference and the volume of semen produced and both physical and morphological semen characteristics (DIAS et al., 2008). In the case of females, the SC also influences their reproductive traits, since there is a genetic correlation between age at first calving, calving interval, pregnancy rate and the scrotal circumference of their 
ancestor (SIQUEIRA et al., 2013). However, using scrotal circumference as the only selection criterion may not be a good alternative when it is sought to improve the reproductive performance of the herd, since SC may have low genetic correlation with some reproductive traits of females, especially if the SC is measured at younger ages (BOLIGON et al., 2007; PEREIRA et al., 2002).

Growth traits have genetic variability, but they can also be influenced by environmental factors. Therefore, environmental factors such as year, month of birth and calf sex are important sources of variation on the performance of calves from birth to 18 monthsand it should be considered when comparing and selecting animals based on these traits.

\section{REFERENCES}

ALENCAR, M.D.; TREMATORE, R.L.; BARBOSA, P.F.; ALMEIDA, M.A.; OLIVEIRA, J.A.L. Desempenho de bezerros filhos de touros das raças Nelore e Canchim e cruzados (F1) Charolês x Nelore e Piemontês $\mathrm{x}$ Nelore. Revista Brasileira de Zootecnia, v.26, n.3, p.461-466, 1997.

ABCZ. Associação Brasileira de Criadores de Zebu. Estudo aponta caminhos para atividade pecuária em MG. Acesso 13 de junho de 2017. Disponível em:

<http://www.abcz.org.br/Home/Conteu do/24538-Estudo-aponta-caminhospara-atividade-pecuaria-em-MG> . 2016.

BOLIGON, A.A.; RORATO, P.R.N.; ALBUQUERQUE, L.G. Correlações genéticas entre medidas de perímetro escrotal e características produtivas e reprodutivas de fêmeas da raça Nelore. Revista Brasileira de Zootecnia, v.36: n.3, p.565-571, 2007.

DIAS, J.C.; DE ANDRADE, V.J.; MARTINS, J.A.M.; EMERICK, L.L.; DO VALE FILHO, V.R. Correlações genéticas e fenotípicas entre características reprodutivas e produtivas de touros da raça Nelore. Pesquisa Agropecuária Brasileira, v.43, n.1, p.53-59, 2008.

FERRAZ FILHO, P.B.; RAMOS, A.A.; SILVA, L.O.C.; SOUZA, J.C.; ALENCAR, M.M. Environmental and genetic influencing pré and postweaning growth traits of Tabapuã cattle in Brazil. Archives Veterinery

Science, v.6, n.2, p.19-30, 2001.

FORNI, S.; ALBUQUERQUE, L.G. Estimates of genetic correlations between days to calving and reproductive and weight traits in Nelore cattle. Journal of Animal Science, v.83, n.7, p.1511-1515, 2005.

LAUREANO, M.M.M.; BOLIGON, A.A.; COSTA, R.B.; FORNI, S.; SEVERO, J.L.P.; ALBUQUERQUE, L.G.D. Estimativas de herdabilidade e tendências genéticas para características de crescimento e reprodutivas em bovinos da raça Nelore. Arquivo Brasileiro de Medecina Veterinária e Zootecnia, v.63, n.1, p.143-152, 2011.

LIMA, F.P.C.; XAVIER, P.R.; BERGMANN, J.A.G.; MARQUES JUNIOR, A.P. Perímetro escrotal e características seminais de touros da raça Nelore selecionados para precocidade sexual. Arquivo Brasileiro 
de Medicina Veterinária e

Zootecnia, v.65, n.6, p.1603-1608, 2013.

MARTINS, G.A.; MARTINS FILHO, R.; LIMA, F.A.M.; LÔBO, R.N.B. Influência de fatores genéticos e de meio sobre o crescimento de bovinos da raça Nelore no estado do Maranhão.

Revista Brasileira de Zootecnia, v.29, n.1, p.103-107, 2000.

ROSA, A.N.; SILVA, L.O.C.; NOBRE, R.C.; MARTINS, E.N.; COSTA, F.P.;

TORRES JUNIOR, R.A.A.;

MENEZES, G.R.O.; FERNANDES,

C.E.S. 2015. Vale a pena investir em touros geneticamente superiores?.

Acesso 11 de setembro de 2017, <https://www.embrapa.br/web/mobile/n oticias/-/noticia/3433131/artigo---valea-pena-investir-em-tourosgeneticamente-superiores> , 2017.

RIBEIRO, J.S.; LADEIRA, M.M.; MACHADO NETO, O. R.; CAMPOS, F.R. Consumo alimentar e sua predição pelos sistemas NRC, CNCPS e BRCorte, para tourinhos zebuínos confinados. Revista Ciência

Agronômica , v. 43, n. 4, p. 802-810, 2012.

PANETO, J.C.C.; LEMOS, D.C.; BEZERRA, L.A.F.; MARTINS FILHO, R.; LÔBO, R.B. Estudo de características quantitativas de crescimento dos 120 aos 550 dias de idade em gado Nelore. Revista

Brasileira de Zootecnia, v.31, n.2, p.668-674, 2000.

PEREIRA, E.; ELER, J.P.; FERRAZ, J.B.S. Análise genética de características reprodutivas na raça
Nelore. Pesquisa Agropecuária

Brasileira, v.37, n.5, p.703-702, 2002.

SAS - STATISTICAL ANALYSES SYSTEM. SAS/STAT user's guide. Cary: SAS Institute, 2004.

SARMENTO, J.L.R.; PIMENTA FILHO, E.C.; RIBERIO, R.M.F.; MARTINS FILHO, R. Efeitos ambientais e genéticos sobre ganho em peso diário de bovinos Nelore no estado da Paraíba. Revista Brasileira de Zootecnia, v.32, n.2, p.325-330, 2003.

SILVA, A.E.D.F.; UNANIAN, M.M.; CORDEIRO, C.M.T.; FREITAS,

A.R. Relação da circunferência escrotal e parâmetros da qualidade do sêmen em touros da raça Nelore PO. Revista Brasileira de Zootecnia, v.31, n.3, p.1157-1165, 2002.

SIQUEIRA, J.B.; GUIMARAES, J.D.; PINHO, R.O. Relação entre perímetro escrotal e características produtivas e reprodutivas em bovinos de corte: uma revisão. Revista Brasileira de Reprodução Animal , v.37, n.1, p.313, 2013.

SOUZA, J.C.; RAMOS, A.A.; SILVA, L.O.C.; FILHO, K.E.; ALENCAR, M.M.; WECHSLER, F.S.;FERRAZ FILHO, P.B. Fatores do ambiente sobre o peso ao desmame de bezerros da raça Nelore em regiões tropicais brasileiras. Ciência Rural,v.30, n.5, p.881-885, 2000.

SOUZA, M.C.A.; FERRAZ FILHO, P.B.; SILVA, L.O.C.; SOUZA, J.C.; MACHADO, C.H.M. Efeitos genéticos e ambientais sobre pesos à desmama de bovinos da raça nelore mocha, na região pecuária oeste São Paulo Paraná. 
Archives of Veterinary Science, v.9, n.2, p.113-118, 2004.
USDA. USDA Agricultural Projections. Acesso 15 setembro de 2017, $<$ https://www.ers.usda.gov/publications/ oce $081>$ 